\title{
Translating insult: Strategies of rendering invective in modern political discourse
}

\author{
Mariia Sevastiuk ${ }^{* 1}$ \\ ${ }^{1}$ Taras Shevchenko National University of Kyiv, Institute of Philology, 14 Shevchenko Blvd, 01601, \\ Kyiv, Ukraine
}

\begin{abstract}
The article focuses on the use of invective in political texts and specifics of its rendering in the English-Ukrainian translation. It aims to define possible strategies for invective translation and factors that influence translator's choice. Since the use of invective by political leaders is aimed primarily at provoking a certain reaction from their opponents and the public, the main criterion of equivalence in the translation of such units is pragmatics, which stipulates the translator's task as trying to make the invective perform the same function in the translation and be perceived in the same way as in the original, often regardless of its language component in the source language. The paper suggests that it becomes possible with the help of pragmatic adaptation, which implies various manipulations with the source text aimed to ensure its better understanding by the receptors of translation. Three main translation strategies of pragmatic adaptation are proposed: neutralization, substitution and stylistic amplification. These strategies dictate the further choice of translator's decisions and the application of translation transformations aiming to preserve the emotional and evaluative load of invective in translation.
\end{abstract}

\section{Introduction}

Modern political communication has changed dramatically over the recent decades. The profound democratization of global society has transformed communicative norms, language tastes and values triggering the active attack of invective on various discourses. The obscene lexical layer and open communicative aggression which had long been considered taboo in world political tradition and culture, became a powerful tool for achieving personal goals and a mechanism for influencing mass consciousness. Today the researchers talk about a whole aggressive discursive system [1-3], which is implemented in the speech of politicians through the extensive use of invectives.

Much of scientific interest has been devoted to defining the notion of inventive and establishing criteria for identifying what constitutes this term across disciplines. The term derived from Latin 'oratio invective', the practice of verbally insulting, attacking and ridiculing an opponent either orally or in writing [4]. The invective is most often associated with an insult, swearing, profanity, obscenity, vulgarity, jargon, slang, etc, often used as a

${ }^{*}$ Corresponding author: maria.sevastiuk@gmail.com 
synonym to these notions. However, as we shall see, both the theoretical definition of invective and its scope vary in different references.

In his seminal work "The field of invective. Swearing as a social problem" Zhelvis defines invective as "a verbal attack against someone or something; condemnation, offensive speech". In other terms, invective is any offensive speech, which aims to offend or humiliate an opponent or any third party. According to the scholar, invectives refer to the part of the national dictionary, which, on the one hand, is uncodified (not allowed for use in a linguacultural situation), or even prohibited in its extreme parts (as taboo words), and on the other hand, is well-known to all members of the given social group. The active use of invective vocabulary testifies to the spiritual and sociocultural level of the speaker and explicates their feelings and emotions [5].

At present, two basic approaches to the definition of the linguistic phenomenon of invective have been established [5-7]. In a broad sense, invective is any verbal expression of aggressive attitude towards the opponent. In its the narrow sense, it is treated as a verbal violation of ethical taboos, which is carried out by taboo language. Another pair of opposing approaches to the nature of invective may be roughly described as linguistically and communicatively oriented ones. If the former regards invectives as merely lexical units, thus limiting them to obscene vocabulary, the latter deals with an invective as a communicative formation, which performs its main function of insult.

The problem of communicative nature of invective is examined in the Theory of speech acts, introduced by Oxford philosopher John Austin and further developed in the works of his disciple John Searle [8-9]. Within its framework, invective is considered a part of interpersonal relations. An invective speech act is a verbal block of insults, which differ from each other in emotional colouring, as well as in the directional motive. An invective speech act differs from a single invective in the presence of an object (a speaker) and a subject (a listener) of speech act perception.

We follow the communicatively oriented approach to the interpretation of the term and define it as a unit of speech, which, being actualized within the communicative strategy of confrontation, aims to negatively evaluate opponents both explicitly and implicitly. In this study we focus mainly on its lexical component, which is manifested in political speeches explicitly, such as low colloquialisms, jargon, slang, vulgarisms, pejorative, negatively coloured, insulting, obscene, scornful, taboo words that contain a seme of insult in their component structure. However, stylistic devices, such as metaphors, irony and sarcasm, are also considered within the research and are identified as a part of invective spectrum, as they help carry the necessary confrontational meanings in political discourse, hiding them under the guise of linguistic richness.

The study concentrates on intentional and goal-oriented invectives which mainly serve such functions as manipulation of the mass consciousness and discrediting one's political opponent/opponents while stirring up an expected emotion and affecting their 'weak spots'.

Rich functional and discursive potential and pragmatic nature of such units raise an important question of proper translation of invectives in political texts, which often become a sensitive material taking into account the ethical question of rendering taboo language in translation but also a challenge of overcoming other lexical, grammatical and cultural inconsistencies which complicate the translator's task. We argue that proper rendering of invectives helps prevent misunderstandings between communicators in the process of intercultural interaction. Moreover, the correct interpretation of the speaker's intention, and, consequently, its adequate reproduction in the translation of political discourse, is one of the fundamental conditions that contribute to the communicative success of high-level talks.

Since applying invectives by political leaders in communication is aimed primarily at provoking a certain reaction from political opponents and the public, the translator cannot focus exclusively on the language component. One of the main tasks is to create a translation 
that would carry the same communicative load and seek to achieve the impact on the recipient intended by the initial addresser. That's why we regard pragmatics as the main equivalence criterion for the reproduction of insulting language in political texts. Pragmatic adaptation is taken as the theoretical framework for the research, so we focus on this notion in the corresponding paragraph and substantiate this choice before proceeding to the analysis of sample material collected.

The research addresses the use of invective in modern American political discourse and specifics of its rendering in the English-Ukrainian translation, which becomes quite a challenging language pair in view of the asymmetry between value orientations systems, traditional norms and political standards of source and target cultures. Hence, the purpose of the study is to identify and describe main translation strategies which are applied to render the pragmatic potential of invective in Ukrainian translations of American political discourse. Particularly, the following research objectives were set:

- to determine which pragmatic changes are often observed in the English-Ukrainian translation of invective in political discourse;

- to single out and describe main adaptive strategies applied to render invective in the translated texts;

- to characterise instances of invective rendering in selected samples and establish any recurrent factors and patterns, that influence the choice of translator's techniques while dealing with political texts.

The results as related to the objectives stated are presented in the subsequent paragraphs.

\section{Methods}

\subsection{Materials}

This study is basically a corpus-based research. It is constituted by two bodies of political texts, one - produced in English, as the source language, and the other - their translations into Ukrainian (target language). The main criterion which predetermined the selection of sample material was the use of invectives applied within the framework of the sphere of political discourse. 35 samples of political rhetoric (10 public speeches and 25 posts on Twitter) have been thoroughly analysed and screened in order to single out the examples of invective use. The research follows the communicative approach, and examines a speech act, containing the use of invectives, as a unit of analysis. To analyse the corpus, $30 \%$ of source texts, which amounts to 24 fragments with a total word count of about 940 words, were selected as the sample. Their oral and written translations into Ukrainian formed the other part of the corpus. For the first part of the corpus, the fragments of American political discourse have been selected as the sample material, since invective is deeply rooted in American political tradition and finds its extensive application in politicians' speeches. The basis of the research has been formed by the presidential rhetoric of former US leader Donald Trump. Since confrontation is a defining feature of the politician's personality, the communicative and expressive functions of the original can be adequately rendered only provided that invective is fully reproduced in translation. The rest of fragments have been taken from texts produced by other well-known American political actors, such as Joe Biden and Bernie Sanders.

\subsection{Procedure}

The study was conducted within the framework of pragmatic adaptation theory. First, we analysed the texts produced by modern American politicians, searching for the instances of invective use. Then the comparative analysis of these fragments and their translations into 
Ukrainian was performed in order to identify the instances of pragmatic shifts. On this stage, each fragment was aligned with its translated Ukrainian counterpart. Then, the samples were classified and labelled as for the character of the shifts which had taken place. It was established, whether the expressiveness of an insult was levelled, intensified or preserved by replacing the invective with corresponding one in the target language. According to the data obtained, three main translation strategies were identified, and all selected examples were analysed from the perspective of these three translation strategies. The method of pragmatic analysis was applied in order to consider the general nature of the text, context and immediate situation of communication, the use of discursive strategies, the role of non-verbal components and paralinguistic means of communication, and other important pragmatic factors. Also, all selected and analysed examples were examined for the presence of recurrent trends and factors of translation strategies use. Taking this into consideration, we have assumed that the translation of such material from English into Ukrainian demonstrates certain patterns and tendencies, which we tried to systematize in the last paragraph.

\section{Theoretical Background}

The end of the last century marked a clear swing to a more practical, open and flexible approach to language and translation, bringing an increased interest to pragmatic aspects of communication, which switches the focus of language studies towards "the relation of signs to interpreters and users" [10]. As stated by the founder of pragmatics Charles Morris, "since the interpreters of most signs are living organisms, [...] it (pragmatics) deals with all psychological, biological and sociological phenomena that are observed in the functioning of signs". These ideas redirected language studies from the realm of semantic meaning of a word and made human factor one of the central concepts in pragmatics. Placing a human at the centre of interest, pragmatics asserts that the impact on the interlocutor is the ultimate purpose of communication.

The study of translation as a communicative act explains a vast interest of translation science in pragmatics. In the process of translation, the source text is redirected to foreign recipients, who become its interpreters. That is why it is extremely important to take into account the pragmatic relations of the source message in order to ensure that the translation is perceived by the recipients with the same reaction as the original text was. However, since the source and target receptors tend to have distinct language experience, conceptual worldviews, and different background knowledge, achieving a communicative goal in translation requires considering social, cultural, psychological, and other differences between the recipients of the source text and the translation. Therefore, the translator is often forced into certain amendments that may help to eliminate these differences. Such manipulations with the original text in order to guarantee a better understanding of translation by the receptors are called pragmatic adaptation.

The pragmatic aspect of translation, together with actual examples of pragmatic adaptation at work (although the term 'pragmatic adaptation' is not necessarily applied), was considered in a number of articles [11-15].

According to Schweizer, pragmatic adaptation is a transformation of the original utterance with due regard for the reproduction of its pragmatic meaning, i.e. the specific perception of information by different recipients [14]. Komissarov draws attention to the fact that in this case it is not about the quality of translation, but about the same reaction of the recipients of the source text and the translation [13]. In Ukrainian translation studies, the term "adaptation" is thoroughly studied by Demetska, who emphasizes the importance of stereotypes and expectations of source and target culture in the process of pragmatic adaptation, and identifies conditions of applying adaptation in translation [11]. A complex research on the pragmatics of translation can be found in Neubert [15]. The scholar regards 
pragmatic adaptation as a means of expanding the audience and establishing potential relationships between the interpreters of the original and the translation. He adds that translation is autonomous and does not depend on the source text in terms of grammar and semantics, but it always owes its pragmatics to the original. Hence, translation becomes a new version of the original text in the new conditions of another language and for a new audience, but its pragmatic aspect, i.e. its impact on the recipient, corresponds to the original.

Bearing in mind that within the framework of pragmatic research an adequate translation is a translation that causes a reaction that coincides with the communicative intention of the sender, the main functions that help convey the pragmatic load of this type of text are communicative and expressive ones [16-17]. The communicative function implies the transmission of essential information. Reproduction of this function in translation involves the fullest rendering of the communicative intent, which is embedded in the text with the help of language units that have the required substantive and connotative meaning. The expressive function is aimed at rendering emotive layers hidden under factual information. This function ensures a high degree of influence of the addressee's speech on the recipient, and therefore insufficient attention to its rendering leads to inadequate translation, weakening the impact on the target audience and distortion of the author's intention.

Considering the completeness of reproduction of negatively coloured units in the translation, as well as the success (or necessity) of the translator's attempts to preserve the expressive and communicative potential of the original invective, we tried to single out and systematise the main techniques a translator can be guided by, resorting to pragmatic adaptation. The identified translation strategies are described in the consequent paragraph, together with the results of sample material analysis.

\section{Discussion and Results}

\subsection{Strategies of Pragmatic adaptation}

The study of the sample material demonstrated main types of pragmatic shifts, which were then analysed and outlined into three basic groups. Based on the type of a pragmatic shift taking place in the translation (whether the expressiveness of an insult was levelled, intensified or preserved by replacing the invective with its equivalent in the target language) we singled out such adaptive strategies as neutralization, substitution and stylistic amplification. These three micro-strategies are implemented in translation with the help of translation transformations. The use of transformations in some cases depends on the translation decisions made by the translator in an attempt to reproduce the pragmatic charge of certain communicative strategies and means of their expression.

A few examples from the analysis of the data related to the strategies of pragmatic adaptation are provided below.

\subsubsection{Neutralization}

Neutralization occurs when it is impossible to convey the entire linguistic, cultural or emotional load of the original message in translation. At the same time some of expressive stylistic devices are levelled or replaced by less strong, or even absolutely neutral ones. This translation strategy is frequently accompanied with such transformations as:

- descriptive translation (a lexical unit of the source language is replaced in the language of translation by a phrase that adequately conveys its meaning);

- generalization (translation of a lexical unit of the source language that has a narrower meaning, with a unit of target language with a broader meaning); 
- $\quad$ or omission (eliminating a word or an expression from the source text in the target text).

The use of neutralization strategy for rendering invective may occur for several reasons. First, a translator may resort to neutralizing insults in order to avoid negative colouring of the source message and trying to soften an assault and make it less offensive. It often occurs when traditions of political rhetoric differ in source and target cultures, setting different acceptable degrees of offensiveness, based on the norms which exist in the given societies. These norms can interfere in the translator's decision-making process and influence the choice of expressive and linguistic means, thus, altering the level of statement's offensiveness.

Example: "The biggest problem this world has is nuclear proliferation. And we have a country out there - North Korea which is sort of wacko, not a bunch of dummies - and they are going out and they are developing nuclear weapons" (Trump).

In the following statement, addressed towards the political leaders of North Korea, former American president Donald Trump uses two invectives at once: "sort of wacko" and "a bunch of dummies". Such a colloquial style of presidential rhetoric and explicit accusation, especially on the international level, is a challenge for translation and forces the translator to choose between two options: preserving the original negative load of invectives or levelling them to some extent in translation. In the following version of the translation, the interpreter resorted to the second option, neutralizing the pejoratives, which in the original language clearly belong to the colloquial and vulgar language, with more stylistically neutral counterparts. This decision led to the partial loss of expressiveness in the translation: "Розповсюдження ядерної зброї- ие найбільша проблема цього світу. Однак, маємо $i$ такі країни, як Північна Корея, керівництво якої хоч і ексиентричне, але точно не дурне - i вони не такі як усі, вони продовжують розробляти ядерну зброю".

The second reason of applying neutralization is culturally motivated nature of invective means of language. Sometimes the expressive function of utterance may be neutralized when the invective is based on a concept from the source culture which does not exist in the target culture and therefore there is a clear need to explain the meaning in order to make the word and all the implied meanings understandable to the target audience, or to eliminate the invective at all, when the context does not allow to use descriptive translation or periphrasis.

For example, this reason often dictates the use of neutralization strategy while rendering invectives which are applied within the confrontation tactics of name-calling often utilized by Donald Trump [18]. It consists in assigning negative nicknames or 'labels' to one's political opponents that are sufficiently expressive to discredit or ridicule the direct addressee, thereby lowering their political scores and undermining their image. These labels are created by combining anthroponyms with insulting adjectives, nouns or expressions, which carry implicit or explicit insult in their meaning (Crooked Hillary, Fat Jerry, Crazy Joe Biden, Hightax Andrew Cuomo).

In addition to the function of invective, these units perform the function of a proper name. Therefore, trying to partially preserve the internal form, the translator should also seek to reproduce semantic and emotional information, which is important for political discourse, trying to convey the speaker's personal attitude to the objects of naming and aiming at some manipulative influence on the listener or reader. Moreover, these nicknames are mainly culturally-bound and represent the realities of American politics or public life. This poses a challenge for translation, which is often resolved with the help of neutralization.

Example: "Lyin' Ted Cruz and 1 for 38 Kasich are unable to beat me on their own so they have to team up (collusion) in a two on one. Shows weakness!" (Trump).

In this example, Donald Trump uses a nickname to address an invective against his fellow Republican and Ohio Gov. John Kasich. A nickname "1 for 38 Kasich" means that in the election, the politician was able to get enough votes only in one of the 38 required states, and aims to emphasize the politician's failure. For an average Ukrainian listener or reader, the 
procedure of the US election campaign is rather an unfamiliar topic, and therefore these figures do not carry any informative load for them. The full semantic and expressive load of this phrase can be conveyed in Ukrainian only with the help of descriptive translation or explanation in non-textual elements. Perhaps that is why the translator decided to omit this 'label' in translation, which to some extent led to the levelling of the pragmatic potential of the whole statement: "У Брехливого Теда Круза і Джона Кейсика не вистачило сил, щуоб перемогти мене самотужки, тому їм довелося об'єднатись удвох проти одного. Вияв слабкості!"

Example: "Phil Bredesen is an absolute total tool of Chuck Schumer. He is a tool of Chuck Shumer and, of course, the MS-13 lover Nancy Pelosi" (Trump).

Speaking out against the leader of the minority faction in the House of Representatives, 79-year-old Nancy Pelosi, during a congress in Nashville, Tennessee, Donald Trump uses the abbreviation "MS-13". Every American knows that the acronym stands for "Mara Salvatrucha," which is a slang name for "El Salvador Ants," and is used to refer to one of the most brutal criminal groups in the world, active in the United States, Mexico, El Salvador and other countries. For the Ukrainian addressee, this name, and especially the abbreviation, does not say anything. This should be taken into account when translating. Moreover, it is quite difficult to preserve the internal form of the nickname "the MS-13 lover Nancy Pelosi" in Ukrainian translation. As in the previous example, the interpreter decided not to overburden translation with verbose explanations. The invective was neutralized and fully omitted in translation: “Філ Бредесен - ие інструмент в руках Чака Шумера. Він $е$ інструментом Чака Шумера і, звичайно, Ненсі Пелосі. ”.

\subsubsection{Substitution}

Stylistic substitution means changing the linguistic expression to similar in their functions linguistic expressions of the target culture. This strategy takes place when the translator does not have corresponding stylistic means for reproducing certain images from the original text. Thus, they substitute these expressions for others, more appropriate and more natural for their language in order to achieve the communicative and expressive functions of the source message and not to lose the emotional load carried by the initial expression.

The use of this strategy may also be substantiated by pragmatic and semantic inconsistencies between invectives in source language and their dictionary equivalents in target language. These units may be equivalent in some context, but have different traditions of use in different cultures, acquire different connotations in the same context, or simply sound unnatural for the target audience.

Example: "The fact is that I've gone head-to-head with Putin and made it clear to him, we're not going to take any of his stuff. He's Putin's puppy. He still refuses to even say anything to Putin about the bounty on the heads of American soldiers" (Biden).

At the presidential debates this year Joe Biden credited Donald Trump with failing to confront Russia, accusing the former US leader of being the "puppy" of Russian President Vladimir Putin. The translator substituted the invective "puppy" with the Ukrainian word "маріонетка", which, not being the dictionary equivalent of the initial word, still fully rendered the meaning of "weak-willed, cowardly person, who can get easily tricked or manipulated" and preserved the intended negative evaluation and expressiveness: " $A$ зустрічався віч-на-віч із Путіним і твердо заявляв йому, що ми не прийматимемо його нісенітниць. Він же є маріонеткою Путіна. Він і досі відмовляється навіть сказати що-небудь Путіну за винагороду за голови американських солдатів".

Example: "Most of the politicians, almost all of them don't even know where they are, where they are being put, they know nothing about these people. This could be the great Trojan Horse of all time" (Trump). 
In his other campaign speech during the Republican convention in Green Bay, Wisconsin, Donald Trump strongly opposed the increase in the flow of migrants from Syria and his opponent - Hillary Clinton - who at the time was openly in favour of this question. Trump drew public attention to the fact that such a wave of refugees could play a nasty joke on the United States and likened this situation with the tragic fate of the ancient city of Troy, which was destroyed from within by the tricky move of the Greeks, who were able to enter the city and set it on fire with the help of a wooden horse. In the Ukrainian version of the translation, the allusion was reproduced by means of the functional equivalent "міна сповільненої діi", which managed to transfer the necessary image embedded in the original, and didn't lead to pragmatic levelling: "Більшість політиків, майже всі, не розуміються в поточній ситуації, в тому, куди їх призначають, вони нічого не знають про конкретних людей. Думаю, ие найбільша міна сповільненої дї̈ усіх часів"

\subsubsection{Stylistic amplification}

Stylistic amplification (or emphatisation) occurs when the translator intentionally emphasizes the expressiveness of the source text, seeking to increase its stylistic or emotional load. The translator can also resort to stylistic amplification as an additional means of compensating for expressive, associative or symbolic losses in translation or as a tool to overcome fundamental differences between the target text and the source in an attempt to bring the communicative effect of translation closer to the original.

Example: While Bette Midler is a rather unattractive woman, I refuse to say that because I always insist on being politically correct (Trump).

Ukrainian translators sometimes increase the level of emotionality of the Englishlanguage invective or even add their own invective in order to strengthen the communicative effect of the image: "Хоч Бетт Мідлер і повне страховисько, я все одно цього не скажу, тому що я завжди намагаюсь бути політично коректним". In the original message a source invective "rather unattractive woman", which is intended to carry a certain insult in the seemingly implicit form, and is only partly intensified with a modifier "rather", was rendered into Ukrainian with the expression "повне страховисько" which has strong negative expressive and evaluative meaning that is even more reinforced with the help of a diminutive suffix.

Example: "It would seem very hard to obstruct justice for a crime that never happened! Witch Hunt!" (Trump).

In one of the responses to his opponents, Donald Trump used the metaphor of "Witch Hunt", which, in addition to its basic meaning in the historical context, in American political slang means an attempt of a group of politicians to unfairly accuse and punish their opponent. The translator transferred the expression with the help of a calque "полювання на відьом", which seems to be a well-motivated decision given that in the Ukrainian language this phrase is also well-known to denote "unjust persecution", and therefore fully contributes to the reproduction of this invective in translation, rendering all the necessary negative and evaluative connotations of the original metaphor: "Здавалося б, дуже важко перешкодити правосуддю за злочин, якого ніколи не було! Кляте полювання на вiдьом!". However, the initial expression was modified in translation with a strong and rather colloquial intensifier "клятий", which has significantly increased the overall expressiveness of the message. Given the dominance of irony and ridicule in the rhetorical spectrum of politics and the need to compensate for the expressive load that is often lost due to ethical differences in the political traditions of the two cultures, this can be regarded as a fully motivated translation decision.

Moreover, it is worth mentioning that sometimes stylistic amplification occurs unintentionally, being caused by differences in source and target cultures' traditions and 
norms. For example, such instances can be found in the Ukrainian translations of the aforementioned name-calling tactics. In the American culture addressing a political opponent by only first name, although more informal, does not sound as unceremonious and disrespectful as it does in the Ukrainian language. In the Ukrainian tradition, which has threecomponent naming system, it is common practice to call people you are not closely acquainted with either by first name and surname, or by first and patronymic name, especially in the field of political or official communication. This cultural difference leads to the increase of expressiveness of such units in Ukrainian translation (e.g. "Sleepy Joe"“Сонько Джо”).

\subsection{Factors that Predetermine the Use of Adaptive Strategies}

After analysing samples of rendering invective described in the previous paragraph, English and Ukrainian texts were juxtaposed in order to decide how and why the proposed strategies of pragmatic adaptation were employed by translators. A few factors are identified and listed below.

\subsubsection{Traditions of political rhetoric}

The American political culture has a long-lasting history of applying invectives and resorting to verbal aggression, which seems now to be regarded more as the trademark of linguistic personality of political leaders, than as an actual assault. The invective has long stepped from the domain of debates and election cycle into everyday 'parliamentary' political language and even into the language of diplomatic and international relationships.

For Ukraine, whose independent political processes are rather young, obscene lexical layer and open communicative aggression have long been considered taboo even in translation and only now with the democratization of the global society are becoming acceptable at the high-level talks. However, a lot of Ukrainian translators and interpreters still prefer mitigating verbal conflict in their translations and neutralize invective language means.

\subsubsection{The nature of verbal abuse}

The Ukrainian language tends to have explicit nature and longs for the maximum clarity, avoiding ambiguities, while English, on the contrary, is rather implicit and seems to leave all images without explanation, thinking that a recipient has sufficient life experience and emotional receptivity to instantly build the necessary association in the mind. This pushes Ukrainian translators to explicate invective, especially hidden irony and mockery, providing a descriptive explanation to their translations and resorting to numerous additions and explanations.

\subsubsection{Cultural and national context}

Representatives of different nations perceive, understand and interpret the same facts of the surrounding reality, including the invective image, not always identically.

For example, a resonant statement by Donald Trump about immigrants from Haiti, El Salvador and some African countries - "Why are we having all these people from shithole countries come here?" - is translated into a number of world languages and can serve a textbook example of the importance of cultural and national context in invective rendering. This statement caused a lot of controversy among the world community of translators, who 
could not agree on one option: whether to adapt similar vulgarities to the norms of political ethics of the host country of translation, or to convey the full spectrum of expressiveness, even if the original expression is so unacceptable for diplomatic rhetoric, as in this case. In some languages, the curse was not only softened, but sometimes even the symbol underlying the invective was radically changed. The most notable were translations made into languages and cultures considerably remote from the source one. The invective "shithole countries" was rendered into Chinese as "countries where birds do not nest", and into Uzbek "countries that have become a lair of snakes". Among the Ukrainian translations of this statement by numerous publications, different levels of expressiveness can be found, e.g. “брудні діри”, “смердючі діри”, “краӥни-дірки”, “забруднені екскрементами краӥни”, “дупа світу”, “зажопинськ”.

It can be concluded that when translating invectives based on the realities, taboos and stereotypes of one language, the most important thing is to reproduce the very intensity of emotional meaning, since the emotional load for such units is sometimes even more important than factual information they convey.

This factor also predetermines the fact that there are certain pragmatic and semantic inconsistencies between similar invectives in two different languages, which make it often impossible to render invectives with the help of their dictionary equivalents from the target language. It should be noted that in some cases the equivalent reproduction of the original content provides a full rendering of pragmatic potential in translation. However, the fact that the author and translation receptors belong to different language groups and cultures often makes the equivalent translation pragmatically inadequate. In this case, the translator has to resort to adaptive strategies of translation, introducing the necessary changes to the text.

\section{Conclusion}

Invective can be considered a powerful tool of politicians' rhetorical spectrum, which serves the functions of influencing and manipulating opponents' and audience's opinion. It is applied within the speeches of politicians as the means of implementing the communicative strategy of confrontation. Rich functional and pragmatic nature of these units requires proper attention to them while rendering. It directs translators' efforts into trying to make invective perform the same function in translation and be perceived in the same way as in the source text, often regardless of its language component in the source language. Two main functions which help convey the pragmatic load of invective in translation of political texts are communicative and expressive ones.

Pragmatic adaptation, which implies various manipulations with the source text aimed to ensure its better understanding by the receptors of translation, has been determined as the main strategy of rendering invective in political texts. Proceeding from the translation analysis of the sample material, we have outlined the main pragmatic changes which take place in the translation of such units. According to the identified groups of pragmatic shifts, expressiveness of an insult is predominantly levelled, intensified or preserved by replacing the invective with its counterpart in the target language. Based on the type of a pragmatic shift in translation such adaptive strategies as neutralization (levelling of a certain cultural or emotional spectrum of the message in translation), substitution (creation of new means of expression that evoke such emotions and perceptions in the recipient culture which are similar to the original ones) and stylistic amplification (stylistic reinforcement that occurs when the translator intentionally emphasizes the expression of the source text means) have been proposed. All the instances of invective rendering in selected samples of American political rhetoric have been analysed from the perspective of these strategies.

Following on from the study results, we have established the recurrent factors, which influence the use of translator's strategies. Aside from the basic lexical and grammatical 
differences between English and Ukrainian languages, the use of adaptive strategies may be explained by the difference in political communication traditions of source and target cultures, different preferences to the expression of conflict in explicit or implicit form, asymmetry between the relative means of expression in the systems of source and target language, as well as the differences in cultural and national contexts, personified by the author and translator, source and target audience. Prospects for further research may include the comprehensive study of each of translation strategies identified in the research and their potential to render invective means in other domains of English-Ukrainian translation, for example in diplomacy translation.

\section{References}

1. E. Sheigal, Power as a concept and category of discourse: a dissertation (Voronezh, 2001)

2. I. Frolova, The regulatory potential of confrontation strategy in English-language discourse: a dissertation (Kharkiv, 2015)

3. L. Slavova, Visnyk Zhytomyr. derzh. un-tu im. Ivana Franka 27, 116-117, 2006. Available at: http://eprints.zu.edu.ua/2210/1/06slldzm.pdf

4. A. Novokhatko, The Invectives of Sallust and Cicero: Critical Edition with Introduction, Translation, and Commentary (Walter de Gruyter, Berlin, 2009)

5. V. Zhelvis, The field of invective. Swearing as a social problem (Ladomir, Moscow, 1997)

6. O. Rebrii, D. Haidar, Studia methodologica 40, 157-162, 2015. Available at: http://studiamethodologica.com.ua/vypusky/studia-40.pdf

7. S. Formanova, Zapysky z ukrayinskoho movoznavstva 26(1), 287-297, 2019. Available at: http://nbuv.gov.ua/UJRN/zukm_2019_26\%281\%29_36

8. J. Austin, How to do things with words (Oxford, 1962)

9. J. Searle, Language in Society, 5, 1-24 (1979)

10. C. Morris, Foundation of the theory of signs (University of Chicago Press, Chicago, 1938)

11. V. Demetska, The theory of adaptation in translation: a dissertation (Kyiv, 2007)

12. A. Greere, Studia Universitatis Babes-Bolyai: Philologia, 45(2), 29-42 (2000)

13. V. Komissarov, TTR, 4(1), 33-47 (1991)

14. A. Schweizer, Translation theory. Status, problems, aspects (Nauka, Moscow, 1988)

15. A. Neubert, Pragmatische Aspekte der Übersetzung (Leipzig, 1968)

16. I. Susov, L. Bezugla, Kultura narodov Prichernomorya 168, 284-287 (2009)

17. Yu. Loboda, The Translation of the Expressive Linguistic Means of English political speeches into Ukrainian (based on speeches of British and US politicians): a dissertation (Kyiv, 2011)

18. M. Sevastiuk, Molodyi vchenyi 7(1), 75-80 (2019). Available at: http://molodyvcheny.in.ua/files/journal/2019/7/17.pdf 